\title{
Traumatic Pancreatitis: A Case Report
}

\author{
Travmatik Pankreatit: Olgu Sunumu
}

\author{
Kasım Turgut, Hakan Oğuztürk, Muhammet Gökhan Turtay, Şükrü Gürbüz, Taner Güven \\ Department of Emergency Medicine, Inönü University Faculty of Medicine, Malatya, Turkey
}

\section{ABSTRACT}

Introduction: Acute pancreatitis is an uncommon disease observed in children; it has different etiological factors from adults. Alcohol and biliary stones are observed as the cause of pancreatitis in adults, whereas drugs, infections, trauma, and anatomical distubances are mostly observed as the cause of pancreatitis in children.

Case Report: We presented a traumatic pancreatitis case of a 13-year-old child, which occured because of a fall on a gravestone while running. He was admitted to our emergency service for abdominal pain and emesis complaints 1 day later.

Conclusion: Traumatic pancreatitis should be considered, particularly in children who are admitted to the emergency service, because of severe abdominal trauma and should be diagnosed urgently.

Keywords: Emergency, pancreatitis, trauma

Received: 06.02.2015 Accepted: 23.03.2015

Available Online Date: 09.04.2015

\section{ÖZET}

Giriş: Akut pankreatit çocuklarda nadir görülen ve etiyolojik açıdan da erişkinlerden farklı olan bir hastalıktır. Erişkinlerde çoğunlukla alkol ve safra taşları pankreatitin sebebi iken, çocuklarda ilaçlar, enfeksiyon, travma ve anatomik bozukluklar daha sık etiyolojik neden olabilmektedir.

Olgu Sunumu: Bu çalışmamızda düşme sonrası karnı mezar taşına çarpan, karın ağrısı ve kusma şikayetleriyle acil servisimize başvuran ve sonrasında travmatik pankreatit tanısı alan 13 yaşındaki bir olguyu sunduk.

Sonuç: Künt batın travması sonrası acil servisimize başvuran hastalarda, özellikle çocuk yaş gruplarında pankreas yaralanmasını aklımıza getirmeli ve hızııa tanı koyucu işlemleri yapmalıyız.

Anahtar Kelimeler: Acil, pankreatit, travma

Geliş Tarihi: 06.02.2015 Kabul Tarihi: 23.03.2015

Çevrimiçi Yayın Tarihi: 09.04.2015

\section{Giriş}

Akut pankreatit çocuklarda nadir görülen ve etiyolojik nedenler bakımından da erişkinlerden farklılı gösteren bir hastalıktır (1). Erişkinlerde alkol ve safra taşları pankreatitin \%60 oranında sebebi iken, çocuklarda ise etiyolojik neden olarak ilaçlar, enfeksiyon, travma ve anatomik bozukluklar sıralanabilir (2). Retroperitonda sahip olduğu korunaklı yeri nedeniyle travmatik yaralanması çok sık olmayan pankreasın, bu durumda tanısı da oldukça zordur. Bu nedenle mortalitesi ve morbiditesi yüksek olan pankreas yaralanmaları, batın travmalı olgularda mutlaka akla getirilmelidir (3).

Bu çalışmamızda, düşme sonrası karnı mezar taşına çarpan ve pankreas yaralanması gerçekleşen bir olguyu sunmayı amaçladık.

\section{Olgu Sunumu}

13 yaşında erkek hasta bir gün önce koşarken karnına mezar taşı gelecek şekilde düştükten sonra, karın ağrısı ve kusma şikayetleri gelişince yakınları tarafından acil servisimize getirildi. Hastanın muayenesinde epigastriumda daha belirgin olmak üzere batın tüm kadranlarda hassasiyet mevcuttu. Diğer sistem muayeneleri ise normaldi. Hastanın kan basıncl;105/61 mmHg nabız: 79/dk solunum sayısı:22/dk olarak ölçüldü. Laboratuvar incelemelerinde Hb; 13,9 g/dL, lökosit; 11200/mm³, trombosit; 231.000/mm³, Aspartat Amino Transferaz (AST); 21U/L, Alanin Amino Transferaz (ALT); 27U/L, serum amilaz; 1441U/L, serum

\section{Address for Correspondence/Yazışma Adresi:}

Kasım Turgut, Department of Emergency Medicine, Inönü University Faculty of Medicine, Malatya, Turkey.

Phone: +905548292240 E-mail: kasimturgut@yahoo.com 


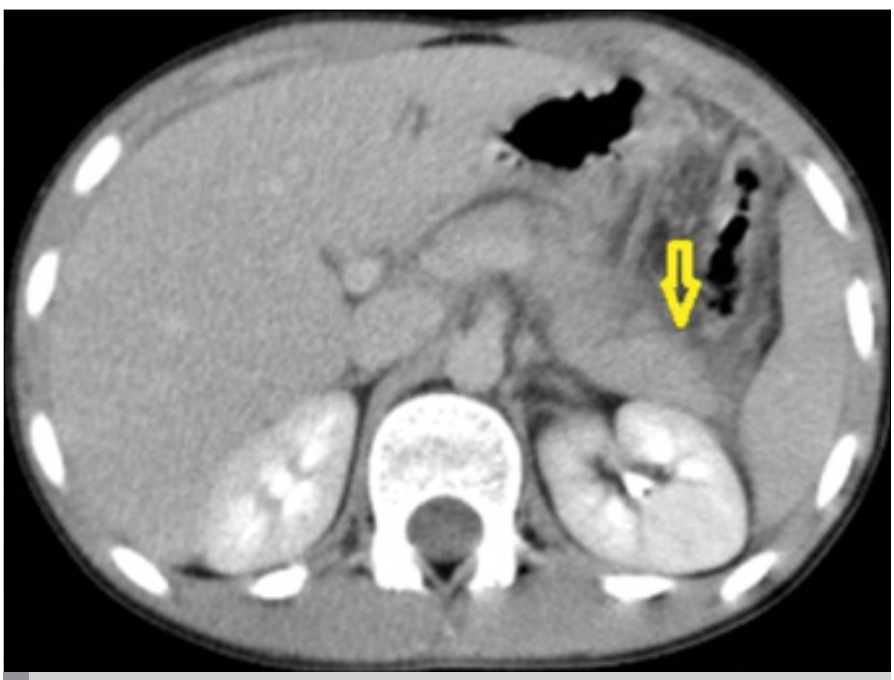

Resim 1. Pankreasta laserasyon

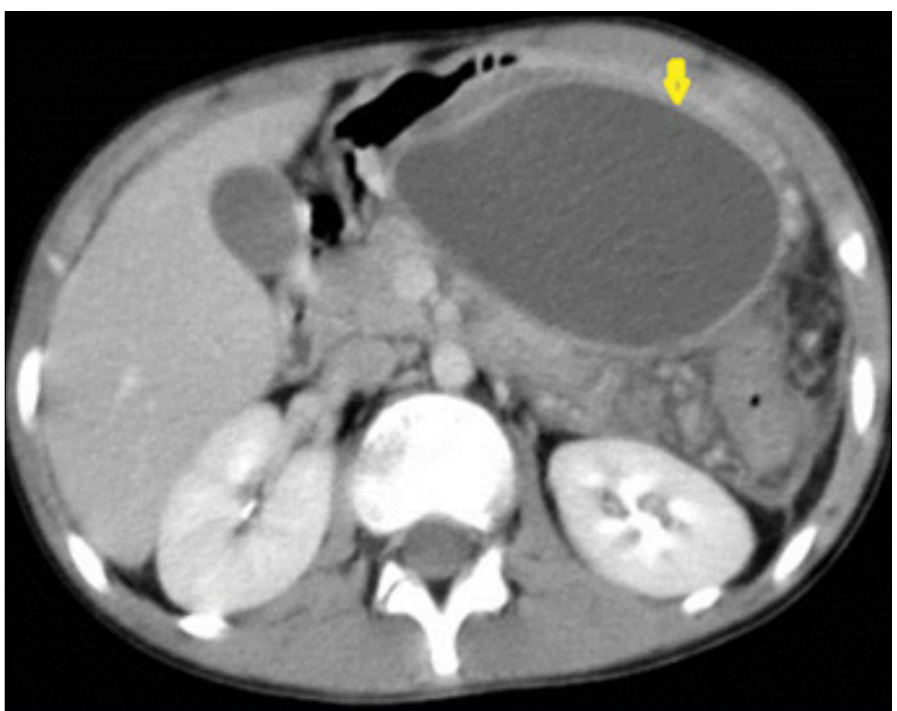

Resim 2. Pankreasta psödokist

lipaz; 1784U/L olarak saptandı. Çekilen batın ultrasonografide (USG) batın içi serbest mayi tespit edildi. Sonrasında alınan batın kontrastlı bilgisayarlı tomografide (BT) ise pankreas gövde, kuyruk birleşim kesiminde laserasyon ve komşuluğunda mayi koleksiyonu görüldü (Resim 1). Hasta mevcut klinik ve laboratuvar bulgularıyla travmatik pankreatit düşünülerek konsülte edildikten sonra çocuk cerrahisi bölümüne yatırıldı. Çocuk cerrahisi yoğun bakımda 20 gün boyunca takip edilen hastanın kontrol tetkiklerinde kan amilaz, lipaz değerleri gerilemeyip, şikayetlerinin de devam etmesi nedeniyle kontrol amaçlı batın BT alındı. BT'de mide posteromediyal kesim komşuluğunda pankreas ile bağlantılı 9,4x5,8 cm boyutta ince duvar (2,2 mm) yapısına sahip psödokist ile uyumlu lezyonlar izlendi (Resim 2). Sonrasında acil cerrahiye alınan hastanın bu kisti drene edildi ve yaklaşık $400 \mathrm{~mL}$ geleni oldu. Ardından kistin açık duvarı ile midenin posterior duvarı süture edilerek anastomoz yapıldı ve böylece kistogastrostomi işlemi tamamlandı. Hasta ameliyat sonrasındaki takiplerinde şikayetleri geriledi ve amilazı düzeldi. Yaklaşık 10 gün daha takip edilen hasta iyileşerek taburcu oldu.

\section{Tartışma}

Çocukluk çağında en sık gözlenen pankreas hastalığı olan pankreatitin, etiyolojik nedenleri erişkinlerden farklıdır. Erişkinlerde safra yollarında taş ve alkol alımı pankreatitten en sık sorumlu tutulan faktörler iken çocuklarda travma, biliyer sistem hastalığı, farmakolojik ajanlar daha sık etken olmakta bunun yanında heredite, enfeksiyonlar ve konjenital anomaliler de etiyolojide rol almaktadır (4). Pankreatitin çocuklardaki etiyolojisi ile ilgili Suzuki ve ark. (5) biliyer problemleri, Nydegger ve ark. (6) ise travmayı, en sık sebep olarak tespit etmişlerdir. Bu kadar geniş olan nedensel dağılıma rağmen yayınların çoğunda travma etiyolojik neden olarak ön sıralarda gözlenmemektedir ( $<\% 2)$. Tüm yaş gruplarında ise travmatik pankreatitlerin \%20'sinin sebebi olarak künt batın yaralanması tespit edilmiştir (7). Bizim olgumuz da mezarlıkta koşarken ayağı takılıp mezar taşının üstüne düşen ve bir gün sonra servisimize karın ağrısı ve kusma şikayetleriyle başvuran künt travma nedenli pankreatit olgusudur.

Pankreas yaralanmalarında klinik ve laboratuvar bulguları nonspesifiktir. Bu yüzden akut evrede tanısı geç konulabilir (7). Hastalar genel olarak karın ağrısı, lökositoz, hiperamilazemi üçlüsü ile başvururlar. Kanda amilaz ve lipaz yüksekliği pankreatik travma açısından anlamlı olsa da özgül değildir. Çünkü tükrük bezi, karaciğer ve duodenum yaralanmalarında da kanda amilaz yükselebilir(8). Ayrıca, künt travmanın olduğu zamandan 3 saat sonra alınan serum amilaz düzeyi, ilk anda alınan değere göre pankreas yaralanmaları için daha sensitif ve spesifiktir (9). Diagnostik peritoneal lavajda (DPL) amilaz görülmesi daha anlamlıdır. USG tanıda ancak pankreas etrafında ödem ve psödokist varsa bize yardımcı olabilir. BT pankreatik travma ve komplikasyonları konusunda USG'ye göre daha aydınlatıcı olup, basit ve en az invaziv olan yöntemdir. Endoskopik retrograd kolanjio pankreatografi (ERCP) ve manyetik rezonanans kolanjio pankreatografi (MRCP) ise invaziv olup özellikle pankreatik duktus yaralanmalarının tanısında işe yarar. Tanısı konulamayan fakat pankreas yaralanması şüphesi devam eden durumlarda son olarak cerrahi işlem tanı ve tedavi edici olarak akla getirilmelidir (8). Bizim olgumuzda hastada karın ağrısı, ı̈kositoz ve hiperamilazemi tespit edildi. USG de ise batın içinde serbest mayi görüldü. Sonrasında alınan kontrastlı batın BT de pankreas laserasyonu görülerek kesin tanı konuldu.

Pankreas yaralanmalarının tedavisinde öncelikle Wirsung kanalının ve duodenumunun yaralanıp yaralanmadığını tespit etmek gerekiyor. Eğer yaralanma yoksa ve hemodinamisi stabilse hasta yoğun bakımda takip edilir. Hastanı oral beslenmesi kesilip, nasogastrik tüp (NG) takılır, mayi verilir. Profilaktik antibiyotik tedavisi ve oktreotid ajanın başlanması tavsiye edilmektedir. Duktus yaralanması varsa endoskopik yöntemle kanala stent yerleştirilebilir fakat cerrahi tedavi de akılda tutulmalıdır. Yalnızca pankreas başı yaralanması varsa eksternal drenaj yeterlidir. Pankreas boyun, gövde kuyruğu ve duktusu içine alan yaralanmalarda distal pankreatektomi ve splenektomi yapılabilir. Duodenumu içine alan yaralanmalarda ise duodenektomi ve pankreatektomi kaçınılmazdır (10). Bizim olgumuzda ise hasta yaklaşık 20 gün boyunca çocuk cerrahisi yoğun bakımda takip edildi. Kontrol tetkiklerinde amilaz, lipazı gerilemeyen ve karın ağrısı devam hastanın kontrol amaçlı alınan tetkiklerinde 
psödokist ile uyumlu lezyonlar izlendi. Yapılan cerrahi ve medikal tedaviler sonucunda hasta iyileşerek taburcu oldu.

\section{Sonuç}

Künt batın travması sonrası acil servisimize başvuran hastalarda, özellikle çocuk yaş gruplarında pankreas yaralanmasını aklımıza getirmeli ve hızlıca tanı koyucu işlemleri yapmalıyız. Bu konuda bize en çok yardımcı olacak yöntemin batın BT olduğunu unutmamalıyız.

Informed Consent: Written informed consent was obtained from patient's father who participated in this case.

Peer-review: Externally peer-reviewed.

Author Contributions: Concept - H.O.; Design - M.G.T.; Supervision - H.O.; Materials - K.T.; Data Collection and/or Processing - T.G.; Analysis and/or Interpretation - K.T.; Literature Review - K.T.; Writer - K.T.; Critical Review - Ş.G.

Conflict of Interest: No conflict of interest was declared by the authors.

Financial Disclosure: The authors declared that this study has received no financial support.

Hasta onamı: Yazılı hasta onamı bu olguya katılan hastanın babasından alınmıştır.

Hakem değerlendirmesi: Dış bağımsız.

Yazar Katkıları: Fikir - H.O.; Tasarım - M.G.T.; Denetleme - H.O.; Malzemeler - K.T.; Veri toplanması ve/veya işlemesi - T.G.; Analiz ve/veya yorum - K.T.; Literatür taraması - K.T.; Yazıyı yazan - K.T.; Eleştirel Innceleme - Ş.G.
Çıkar Çatışması: Yazarlar çıkar çatışması bildirmemişlerdir.

Finansal Destek: Yazarlar bu çalışma için finansal destek almadıklarını beyan etmişlerdir.

\section{Kaynaklar}

1. Dixit $P$, Sharma $V$, Singh KR, Thapa BR, Rathore M. Conservative management of a case of traumatic pancreatitis in childhood: a case report. Eur Rev Med Pharmacol Sci 2014; 18: 1687-9.

2. Suzuki M, Sai J.K, Shimizu T. Acute pancreatitis in children and adolescents. World J Gastrointest Pathophysiol 2014; 15; 5: 416-26. [CrossRef]

3. Feliciano DV, Mattox KL, Moore EE. Trauma, 6th Edition chapter 35. 2008 McGraw-Hill.

4. Özçakır E, Mercan MH, Kırıştıoğlu İ, Doğruyol H. Pankreatitli olgularda deneyimimiz. Çocuk Cerrahisi Dergisi 2010; 24: 71-6.

5. Suzuki M, Fujii T, Takahiro K, Ohtsuka Y, Nagata S, Shimizu T. Scoring system for the severity of acute pancreatitis in children. Pancreas 2008; 37: 222-3. [CrossRef]

6. Nydegger A, Couper RT, Oliver MR. Childhood pancreatitis. J Gastroenterol Hepatol 2006; 21: 499-509. [CrossRef]

7. Vijay A, Abdelrahman H, El-Menyar A, Al-Thani H. Early laparoscopic approach to pancreatic injury following blunt abdominal trauma. J Surg Case Rep 2014; 12: 1-3. [CrossRef]

8. Debi U, Kaur R, Prasad KK, Sinha SK, Sinha A, Singh K. Pancreatic trauma: A concise review. World J Gastroenterol 2013; 19: 9003-11. [CrossRef]

9. Ustundag M, Orak M, Güloglu C, Sayhan MB, Uysal E. Bisikletten düşme sonrası gelişen akut pankreatit olgusu. Dirim 2006; 81: 300-3.

10. Ankouz A, Elbouhadouti H, Lamrani J, Taleb KA, Louchi A. Pancreatic transection due to blunt trauma. J Emerg Trauma Shock 2010; 3: 76-8. [CrossRef] 